\title{
Bursting the bubble: why sustainability initiatives often lack adequate intention to action translation
}

\author{
Lubna Rashid
}

Accepted: 3 January 2022 / Published online: 20 January 2022

(C) The Author(s) 2022

Terms like sustainable development, radical innovation, diversity and inclusion, and circularity and zerowaste have become common buzzwords in the worlds of business, politics, and media, attracting substantial scholarly attention (e.g., Anand et al., 2021). There is indeed a rising recognition amongst academics, practitioners and the general public alike of the gravity of (looming) social and environmental crises, the cruciality of bottom-up development and empowerment at the grassroots level, and the importance of democratizing and greenifying economic structures, away from mere replicas of Silicon Valley models and GDP-based growth evaluations (Audretsch, 2021; Audretsch \& Moog, 2020; Easterly, 2008; Friederici et al., 2020; Kuratko \& Audretsch, 2021; Moyo, 2009; Pansera \& Fressoli, 2020; Sarasvathy, 2004).

Nevertheless, it appears as though many initiators of altruism-motivated, "world-transforming" ideas and projects dwell in an idealistic bubble of unattainable goals and inadequate strategies that fall short of mirroring, not to mention "fixing," the real world. Those observations are echoed by members of the scholarly community, such as Morris et al.'s (2021, p. 1103) realization that "social value creation is often messy and inefficient" and that "the

\section{Rashid $(\bowtie)$}

Chair of Entrepreneurship and Innovation Management, Technische Universität Berlin, Straße des 17. Juni 135, 10623 Berlin, Germany

e-mail: lubna.rashid@campus.tu-berlin.de process is chaotic, unpredictable, and uncontrollable." Anand et. al (2021, p. 15) point out that "the inability to adequately discriminate between good and bad performers [in sustainable entrepreneurship], and between positive and negative wider sustainability impacts, opens the door for symbolism and organized hypocrisy," calling for "research that enables sustainable entrepreneurs and their stakeholders to more precisely capture their sustainability performance and impacts." Additionally, a review of social, sustainable, and environmental entrepreneurship literature uncovers the "limited acknowledgement of root causes of unsustainability," "a limitation in existing research with respect to complex systems and holistic thinking," and that "critical reflection largely remains unacknowledged in research" (Schaefer et al., 2015, pp. 405-407).

This highly resonates with my personal experiences. Upon entering the world of sustainable entrepreneurship both as a researcher and practitioner, I recall my initial child-like excitement at having landed amidst what felt like the crème-de-la-crème of world-changing communities. I also remember this excitement slowly fading, as I realized that although the intentions in such circles are largely "good" (e.g., O'Shea et al., 2021; Rashid \& Cepeda-Garcia, 2021; Stirzaker et al., 2021), they often translate into actions and strategies that hamper their realization. For instance, I observed that efforts aiming to support human rights and social justice often lack conversation, collaboration, and co-empowerment amongst 
various social segments, while many of those that fight for refugee rights, climate action, or defunding the police have little understanding of the roots and complexities of those intricate issues. I was struck by how often terms like "unethical," "extremist," or "unsustainable," are used without having developed a fundamental understanding of the determinants and drivers behind those condemned human actions, while pushing to fulfil unrealistic goals through rapid, radical, and revolutionary solutions to inherited human behaviors that were years and years in development.

Combining observations and findings from prominent scholarly works in multidisciplinary fields, such as management, psychology, sociology, and biology, with personal reflection, this article critically analyses some of the root causes behind discrepancies in the intention to action translation of prosocially and proenvironmentally motivated initiatives. This is particularly relevant yet not limited to the field of sustainable entrepreneurship, with the hope of ultimately supporting the transformation of rosy bubbles to differentiated, colorful, spectrums of clearsighted, expanded and reflected endeavors.

\section{Learningless education}

Over the past years, I have become increasingly aware of the fact that most people that I have come across, whether social startup founders in Berlin, peach farmers in Georgia, religion teachers in Jordan, or humanitarian rescue workers on the Serbian-Croatian border, share strikingly similar intentions. Humans are all highly driven by primal needs for safety and survival (Aldefer, 1969; Maslow, 1954; Mobbs et al., 2015; Nicholson, 1998; Slavich, 2020), sometimes translating into a radical "flight" response and avoiding anything and anyone new and different, other times an extreme "fight" response and taking the streets by storm in demonstrations for change, though mostly somewhere in between. Our actions as a species are more likely motivated by fear, or lack of safety, than hate; which itself is a secondary emotion often resulting from fear (Shapiro, 2016; van Stekelenburg, 2017). Without keeping this in mind, we may easily fall into the fruitless and often divisive cycles of "cancel culture" and "othering" (Barak, 2019; Mueller, 2021; Ulus, 2019), which lead to further reduction of inclusion, empathy, and collaboration between siloed social groups. Those excluded may range from middle-aged white neighbors to queeridentifying individuals; in other words, a result could be the disengagement from values of benevolence and social harmony in those who wish to exude them the most (Bandura, 2002; Bandura et al., 1996).

I certainly wish I had learned this earlier in life. Alas, I had no exposure to psychology until my doctoral studies, and I was never taught critical thinking, emotional intelligence, or empathy skills at any stage of my formal education-but how many of us actually were? (Benson, 2006). We still live in a world where teachers mainly act as disciplinarian, unilateral information sources rather than facilitators of knowledge synthesis and discovery (Rashid, 2019), which leaves much of the responsibility of relearning and unlearning on our adult selves. This is further complicated by the incredible hurdles facing non-academic audiences in accessing scientific knowledge. Entrepreneurs, decision makers, and practitioners are often stuck behind paywalls when attempting to access valid peer-reviewed resources relevant to their life and work (which ironically includes a good chunk of the references I cited in this very article), and if they succeed to do so, they are confronted with academic manuscripts that are written in a language only understandable by a privileged few.

With things standing as they are, reading motivational blogs, engaging with social media, watching influencer videos, and attending career and life coaching sessions have become prominent means in which organizational leaders and aspiring changemakers gain inspiration and knowledge (Margalida \& Donázar, 2020; Schou et al., 2021; Segers et al., 2017; Strenger \& Ruttenberg, 2008). While democratizing knowledge generation, the ease of digital learning access, and the availability of support at the click of a button come with obvious benefits, a complete replacement of science books by social media feeds and specialized professionals by spiritual coaches risks misinformation perpetuation and long-term mental health consequences (see Aboujaoude, 2020; Spohr, 2017). The normalization of mass information pursuit and consumption through largely nonscientific and algorithm-curated knowledge sources may also reinforce "selective exposure" to information that matches consumers' own views and ideologies, including existing biases and predispositions. 
Ultimately, knowledge consumers ought to contemplate what kind of knowledge they are absorbing and translating into action, as much as knowledge producers need to reflect on the motivations, strategies, and implications of creating and disseminating it the way they do.

Though efforts to bridge the industry-academia gap are underway (e.g., Bergmann et al., 2019; Perea \& Brady, 2017), a mindset change among educators and academic researchers and the willingness to do science for science's true purpose (i.e., uncovering truths and generating problem-solving knowledge) rather than mere publish-or-perish, prestige, or financial motivations is crucial toward fostering information access in a more balanced and objective manner (for further reading see Connelly et al., 2021; and Gibb, 2020). It would support proactive selfeducation by means of empirically founded scientific resources on the true causes and consequences of major sustainability issues (Angeloni, 2020) as well as the motivation and reasoning behind some individuals' disagreement with or even denial of them. This may inspire well-intentioned entrepreneurs and activists to instigate intrinsically motivated change toward more sustainable behavioral patterns rather than "in your face" solutions that may lack empathy and "realworld" connection (Deci \& Ryan, 2015; Deci et al., 2017). At the very least, it may enhance one's own wellbeing and peace-of-mind to realize that most humans out there are often striving for safety and survival, albeit in very different ways, rather than intentionally causing harm (see for example Wullenkord \& Reese, 2021).

\section{Exclusive inclusion}

One thing that dawned on me while working with migrant support initiatives is the lack of migrant involvement in the design of those very initiatives, just as I was the only non-white person involved in the management of a startup incubation program aiming to address the global plastic waste problem. It appears that much of the recent movement in support of innovative (business) solutions to major sustainability challenges is dominated by individuals from social groups that are themselves amongst the least impacted by the negative consequences of the social and ecological challenges they address. Recent narratives support this, with examples ranging from the leadership of digital entrepreneurship ecosystems in Africa (Friederici et al., 2020), healthcare artificial intelligence system development in the USA (Ledford, 2019), and climate change protests (Kale, 2020).

Studies have even found patterns of exclusion in organizations and initiatives explicitly aiming at inclusion as part of their core mission and vision. For instance, "businesses that seek to empower subsistence farmers tend to include more productive firms in their supply chain, and those aiming to create employment opportunities [for the base of the pyramid] hire the relatively skilled rather than the very poor" (Lashitew et al., 2021, p. 16). Another example is related to migrant and refugee integration through entrepreneurship, where hints of labeling and categorization emerge toward those targeted for inclusion that risk reproducing the very stereotypes that are meant to be eliminated through those efforts (Högberg et al., 2016; Rashid \& Cepeda-Garcia, 2021).

It can be great to work with people with a similar mindset and cultural background; team homogeneity might indeed be less challenging (e.g., Grossman et al., 2021; Holck, 2018), and minimizing contact with humans that might emotionally trigger us and challenge our views of safety and normality is a valid self-protection mechanism (Festinger et al., 2008). But how can one genuinely expect to "save the world" when most of the world is not included in major decision-making processes? It is unfortunate to remain in exclusive and elitist bubbles, particularly within incredibly diverse and metropolitan cities where no shortage of cultural backgrounds exists, while digital technologies enable access to virtually anyone anywhere.

Though self-education and active learning on those issues are essential, they do not replace actual contact with humans from different walks of life. This may not only improve organizational performance (e.g., Kouame et al., 2015; Vandenbroucke et al., 2016), but bring in valuable perspectives that one might otherwise not typically consider (see Minton et al., 2020), ultimately enhancing impact and reach. Inclusion also paves the way toward abolishing toxic colonial power dynamics (Abdelnour \& Abu Moghli, 2021), while eliminating and/or reclaiming associated stigmatizing terminologies and categorizations that may perpetuate inequalities and social hierarchies. 
So perhaps when taking concrete steps to translate sustainability intention to action, one can take a step back and ponder: How many of the many refugees in my city have I engaged when building my refugee integration project, and how? With how many of my older car-owning neighbors have I discussed my green mobility business idea? If my project has actually grown to encompass a couple dozen or more people, is anyone involved actually from a less privileged upbringing? If yes, am I actively engaging them in brainstorming and creative processes? Am I ready to humbly sit back, listen, reflect, and take notes as they generate ideas, concepts, and solutions stemming from their own valuable experiences, regardless of my own insecurities or biases? After all, even the most universal of current global challenges are likely to impact already disadvantaged individuals more than others (Hallegatte \& Rozenberg, 2017; Pereira $\&$ Patel, 2021), and their expertise in their own needs and conditions should be allowed a seat at the head of the table.

\section{Unmindful reflection}

I am constantly astonished by the myriad of nicelooking and expensive consumer products flooding the markets with privileged, niche customers in mind (see Luchs et al., 2012), on the premise that they are "plastic-free," "organic", or "carbon-neutral," marketed in a way that attempts to convince buyers that they would be "saving the world" if they choose to buy them. While it is in principle a good thing to shift to eco-friendly and ethically sourced products, this phenomenon not only perpetuates the belief that sustainability is only for the rich (e.g., Ritch \& Schröder, 2012; also see Hanson, 2017; Stine, 2019 for some stories)-again excluding those who suffer from sustainability-related challenges the most-but is often also a reinforcement of the very capitalist and consumerist structures that sustainability-focused initiatives and businesses claim and aim to fight (Fyke \& Buzzanell, 2013).

In reality, "if a term [like sustainable entrepreneurship] captures everything then it represents nothing" (Shepherd \& Patzelt, 2011, p. 142). The currently common notion of sustainability, namely the harmonic co-existence and development of economy, ecology, and society, is likely impossible to attain
(Funnell, 2021), while the United Nations Sustainable Development Goals (UN SDGs) are marred with self-contradictions and unrealistic expectations (Kratzer et al., 2021). Promoting industrialization and economic growth increases consumption and carbon emissions (Dhara \& Singh, 2021; Giampietro \& Funtowicz, 2020; Kratzer, 2020), while the greening of cities drives gentrification (Checker, 2011), expanding medical care and health measures increases plastic waste production (Joseph et al., 2021), and sustainability education may lead to emotional burden and distress (Longo et al., 2019). Focusing on one aspect of sustainable development inevitably compromises another, and viewing the issue from an expanded perspective is essential to set attainable goals and realistic agendas. Besides, having a too narrow focus on a specific type of problem, market, geography, or academic field may lead to a loss of sight of the macrolevel implications of well-intentioned micro-level actions.

It would be foolish to argue that in-depth focus on a particular issue is problematic, or that specialists are not needed. I also acknowledge efforts such as discrimination pricing (Kurtis \& Mont, 2020) and multi-level impact modeling (Breuer et al., 2018) that aim to target some of the aforementioned issues. I am, however, urging those investing in making positive change in the world to prioritize taking the time to reflect on the bigger picture, to be ultimately able to set reasonable and realizable expectations and accept one's own limitations. We have become great at running the hamster wheel without necessarily pondering how and why the hamster got in the wheel in the first place. Allowing ourselves to pause the run and ask "big questions" is key to understanding the complex, interconnected systems in which we find ourselves, and the reality of the type and extent of impact that we (can) generate (Harari, 2018; Patel et al., 2018; van Goethem et al., 2014).

Moreover, pausing the run is essential to exit the "hedonic treadmill" and enhance the long-term wellbeing of those that mean well (Brickman \& Campbell, 1971), particularly given the high prevalence of burnout amongst frontline workers (Patel et al., 2018) and the association of prosocial motivation with life dissatisfaction (Kibler et al., 2019). This ultimately risks the development of apathetic, hostile, and discriminatory behaviors toward the very recipients of support (Patel et al., 2018; Sumner \& Kinsella, 2021; 
for more on compassion fatigue see Figley, 2002). We simply cannot sustainably address the needs of others without taking care of our own, which may require substantial lifestyle and mindset changes beyond the occasional three-minute lunchbreak meditation (Engel et al., 2020).

\section{The way ahead}

Having been born and raised in a family and community too incapable, and perhaps somewhat unwilling, to prioritize sustainable behaviors and lifestyle habits over seemingly endless cycles of reactive fire extinguishing, I certainly felt a sense of relief as I ultimately settled in one of the safest, wealthiest, most stable parts of the world. I had learned to attribute my folk's (self- and environmentally) detrimental practices to early-life trauma (Jirsaraie et al., 2019; van der Kolk et al., 1991), feelings of powerlessness and low self-efficacy (Bandura, 1997a, b, 2010; Benight \& Bandura, 2004; Iqbal et al., 2020; Sawitri et al., 2015), years of training in pursuing the fulfillment of mere existence rather than growth needs (Aldefer, 1969; de Haan et al., 2014; Maslow, 1954), and yearlong subjection to contextual resource scarcity (Steg \& Vlek, 2009), educational system failures (Rashid, 2019), and structural abuses, thanks to decades of life in one of the world's most violent contexts.

This is certainly not the story of one family or folk. It is projected that by $2050,3.3$ billion individuals would be living in conflict-prone, fragile contexts with high "exposure to risk and insufficient coping capacity of the state, system and/or communities to manage, absorb, or mitigate those risks" (OECD, 2016, p. 2). In other parts of the world where resources are in abundance, a democratic system is in force, and humans appear to have much reason to feel safe, optimistic, and empowered, there lies much potential as well as responsibility to take the lead in terms of visionary "world-saving" action and reflected, vigorous, extensive, and innovative sustainability strategies and practices (Spence et al., 2011), particularly given the (historical) role that more powerful, western countries play(ed) in creating and perpetuating humanitarian and ecological adversities elsewhere in the world (e.g., Melber, 2020; Ritchie \& Roser, 2018; Wezeman et al., 2021).
While there is certainly progress in that direction, current strategies and actions do not necessarily measure up to initial goals and expectations, even when initiated by the most resourceful and altruistic of founders and innovators. We cannot truly solve grand challenges in our complex surroundings without prioritizing the inclusion of those outside of our circles in the process, constantly educating ourselves on the most rational, fact-based, and empathetic solutions, and taking the time and energy to contemplate and fathom the grand challenges that reside outside as well as within our complex selves.

This might seem daunting and complicated, yet feasible and achievable if we keep in mind that including, learning, and reflecting require time and patience. Expecting lasting change to occur through radical, quick-gains-focused approaches is often simply not possible; if anything, "this myth of magical transformation conflicts with science. Our brains are composed of billions of neurons connected to one another through myriad pathways. Changing basic patterns of thought, feeling, and action requires that billions of new connections be formed. Such a process must be fed by constant experiential input and is therefore inevitably gradual" (Strenger \& Ruttenberg, 2008, p. 5). Inclusive, educated, and reflected, rather than magical, transformation may finally pave the way out of temporary, dissonant, and reactionary solutions (Festinger, 1957) and toward those that capture the true essence of sustainability.

Acknowledgements I am much grateful for the inspiration, trust, and support of Clemens Möckel, Marc Karahan, and David Audretsch. I would also like to thank Jan Kratzer, Karina Cagarman, and the entire EIM team for the space safe and supportive work environment. Thanks also to the anonymous reviewer for the valuable feedback.

Funding Open Access funding enabled and organized by Projekt DEAL.

Open Access This article is licensed under a Creative Commons Attribution 4.0 International License, which permits use, sharing, adaptation, distribution and reproduction in any medium or format, as long as you give appropriate credit to the original author(s) and the source, provide a link to the Creative Commons licence, and indicate if changes were made. The images or other third party material in this article are included in the article's Creative Commons licence, unless indicated otherwise in a credit line to the material. If material is not included in the article's Creative Commons licence and your intended use is not permitted by statutory regulation or exceeds the permitted use, you will need to obtain permission directly 
from the copyright holder. To view a copy of this licence, visit http://creativecommons.org/licenses/by/4.0/.

\section{References}

Abdelnour, S., \& Abu Moghli, M. (2021). Researching Violent Contexts: A Call for Political Reflexivity. Organization. https://doi.org/10.1177/13505084211030646

Aboujaoude, E. (2020). Where Life Coaching Ends and Therapy Begins: Toward a Less Confusing Treatment Landscape. Perspectives on Psychological Science, 15(4), 973977. https://doi.org/10.1177/1745691620904962

Aldefer, C. P. (1969). An Empirical Test of a New Theory of Human Needs. Organizational Behavior and Human Performance, 4(2), 142-175. https://doi.org/10.1016/00305073(69)90004-X

Anand, A., Argade, P., Barkemeyer, R., \& Salignac, F. (2021). Trends and Patterns in Sustainable Entrepreneurship Research: A Bibliometric Review and Research Agenda. Journal of Business Venturing, 36, 106092. https://doi. org/10.1016/j.jbusvent.2021.106092

Angeloni, S. (2020). Education First: What Really Matters in Working for Sustainability. Futures, 120, 102552. https:// doi.org/10.1016/j.futures.2020.102552

Audretsch, D. (2021). Have we Oversold the Silicon Valley Model of Entrepreneurship? Small Business Economics, 56(2), 849-856. https://doi.org/10.1007/ s11187-019-00272-4

Audretsch, D., \& Moog, P. (2020). Democracy and Entrepreneurship. Entrepreneurship Theory \& Practice. https:// doi.org/10.1177/1042258720943307

Bandura, A. (1977a). Self-efficacy: Toward a Unifying Theory of Behavioral Change. Psychological Review, 84(2), 191215. https://doi.org/10.1016/0146-6402(78)90002-4

Bandura, A. (1997). Self-Efficacy-The Exercise of Control. Broadway, UK: Worth Publishers.

Bandura, A. (2002). Selective Moral Disengagement in the Exercise of Moral Agency. Journal of Moral Education, 31(2), 101-119. https://doi.org/10.1080/0305724022 014322

Bandura, A. (2010). Self-Efficacy. In I. B. Weiner \& W. E. Craighead (Eds.), The Corsini Encyclopedia of Psychology. John Wiley \& Sons. https://doi.org/10.1002/97804 70479216.corpsy0836

Bandura, A., Barbarnelli, C., Caprara, G. V., \& Pastorelli, C. (1996). Mechanisms of Moral Disengagement in the Exercise of Moral Agency. Journal of Personality and Social Psychology, 71(2), 364-374. https://doi.org/10. 1037/0022-3514.71.2.364

Barak, M. E. M. (2019). Erecting Walls Versus Tearing Them Down: Inclusion and the (False) Paradox of Diversity in Times of Economic Upheaval. European Management Review, 16(4), 937-955. https://doi.org/10.1111/emre. 12302

Benight, C. C., \& Bandura, A. (2004). Social Cognitive Theory of Posttraumatic Recovery: The Role of Perceived Self-Efficacy. Behaviour Research and Therapy, 42(10), 1129-1148. https://doi.org/10.1016/j.brat.2003.08.008
Benson, P. L. (2006). All Kids are our Kids: What Communities Must Do to Raise Caring and Responsible Children and Adolescents (2nd ed.). San Francisco, CA: Jossey-Bass.

Bergmann, M., Ganz, K., Neufend, M., \& Wrzesinski, M. (2019). Open Access Futures: Time to Push for ScholarLed Publishing [Humboldt Institute for Internet and Society]. Digital Society Blog. https://www.hiig.de/en/ open-access-futures-time-to-push-for-scholar-led-publi shing/

Breuer, H., Fichter, K., Lüdeke-Freund, F., \& Tiemann, I. (2018). Sustainability-Oriented Business Model Development: Principles, Criteria and Tools. International Journal of Business Venturing, 10(2), 256-286.

Brickman, P., \& Campbell, D. T. (1971). Hedonic Relativism and Planning the Good Science. In M. Appley (Ed.), Adaptation Level Theory: A Symposium (pp. 287302). New York, USA; Academic Press.

Checker, M. (2011). Wiped Out by the "Greenwave": Environmental Gentrification and the Paradoxical Politics of Urban Sustainability. City \& Society, 23(2), 210-229. https://doi.org/10.1111/j.1548-744X.2011.01063.x

Connelly, S., Vanderhoven, D., Rutherfoord, R., Richardson, L., \& Matthews, P. (2021). Translating Research for Policy: The Importance of Equivalence, Function, and Loyalty. Humanities and Social Sciences Communications, 8 , 191. https://doi.org/10.1057/s41599-021-00873-z

de Haan, F. J., Ferguson, B. C., Adamowicz, R. C., Johnstone, P., Brown, R. R., \& Wong, T. H. F. (2014). The Needs of Society: A New Understanding of Transitions, Sustainability and Liveability. Technological Forecasting and Social Change, 85, 121-132. https://doi.org/10.1016/j. techfore.2013.09.005

Deci, E. L., \& Ryan, R. (2015). Self-Determination Theory. Elsevier.

Deci, E. L., Olafsen, A. H., \& Ryan, R. M. (2017). Self-Determination Theory in Work Organizations: The State of a Science. Annual Review of Organizational Psychology and Organizational Behavior, 4, 19-43.

Dhara, C., \& Singh, V. (2021). The Elephant in the Room: Why Transformative Education Must Address the Problem of Endless Exponential Economic Growth [Preprint]. https:// arxiv.org/abs/2101.07467

Easterly, W. (2008). Institutions: Top Down or Bottom Up? American Economic Review: Papers \& Proceedings, 98(2), 95-99.

Engel, Y., Ramesh, A., \& Steiner, N. (2020). Powered by Compassion: The Effect of Loving-Kindness Meditation on Entrepreneurs' Sustainable Decision-Making. Journal of Business Venturing, 35(6), 105986. https://doi.org/10. 1016/j.jbusvent.2019.105986

Festinger, L. (1957). Theory of Cognitive Dissonance. Stanford University Press.

Festinger, L., Riecken, H., \& Schachter, S. (2008). When Prophecy Fails: A Social and Psychological Study of a Modern Group that Predicted the Destruction of the World. London, UK: Pinter \& Martin Ltd.

Figley, C. R. (2002). Treating Compassion Fatigue. Milton Park, Abingdon, Oxfordshirev: Brunner-Routledge. 
Friederici, N., Wahome, M., \& Graham, M. (2020). Digital Entrepreneurship in Africa - How A Continent Is Escaping Silicon Valley's Long Shadow. The MIT Press.

Funnell, A. (2021). Sustainable Development Won't Solve Environmental Crises, Say These Experts. It's Simpler Than That. ABC Radio National. https://www.abc.net.au/ news/2021-10-07/the-myth-of-sustainable-development/ 100504448

Fyke, J. P., \& Buzzanell, P. M. (2013). The Ethics of Conscious Capitalism: Wicked Problems in Leading Change and Changing Leaders. Human Relations, 66(12), 1619-1644. https://doi.org/10.1177/0018726713485306

Giampietro, M., \& Funtowicz, S. O. (2020). From Elite Folk Science to the Policy Legend of the Circular Economy. Environmental Science \& Policy, 109, 64-72. https://doi. org/10.1016/j.envsci.2020.04.012

Gibb, B. C. (2020). The Seven Deadly Sins. Nature Chemistry, 12, 104-106. https://doi.org/10.1038/s41557-019-0408-5

Grossman, R., Campo, M. S., Feitosa, J., \& Salas, E. (2021). Cross-Cultural Perspectives on Collaboration: Differences Between the Middle East and the United States. Journal of Business Research, 129, 2-13. https://doi.org/10.1016/j. jbusres.2021.02.031

Hallegatte, S., \& Rozenberg, J. (2017). Climate Change Through a Poverty Lens. Nature Climate Change, 7, 250256. https://doi.org/10.1038/nclimate3253

Hanson, M. (2017). Enough with the beeswax Food Wrap and $£ 18$ Nappies-Eco Living Shouldn’t Be a Luxury. The Guardian. https://www.theguardian.com/sustainablebusiness/2017/may/18/-beeswax-food-wrap-nappies-ecoliving-luxury-plastic-alternatives

Harari, Y. N. (2018). 21 Lessons for the 21st Century. Jonathan Cape.

Högberg, L., Schölin, T., Ram, M., \& Jones, T. (2016). Categorising and Labelling Entrepreneurs: Business Support Organisations Constructing the Other through Prefixes of Ethnicity and Immigrantship. International Small Business Journal, 34(3), 242-260. https://doi.org/10.1177/ 0266242614555877

Holck, L. (2018). Unequal by Structure: Exploring the Structural Embeddedness of Organizational Diversity. Organization, 25(2), 242-259. https://doi.org/10.1177/13505 08417721337

Iqbal, Q., Ahmad, N. H., Nasim, A., \& Khan, S. A. R. (2020). A Moderated-Mediation Analysis of Psychological Empowerment: Sustainable Leadership and Sustainable Performance. Journal of Cleaner Production, 262, 121429. https://doi.org/10.1016/j.jclepro.2020.121429

Jirsaraie, R. J., Ranby, K. W., \& Albeck, D. S. (2019). Early Life Stress Moderates the Relationship Between Age and Prosocial Behaviors. Child Abuse \& Neglect, 94, 104029. https://doi.org/10.1016/j.chiabu.2019.104029

Joseph, B., James, J., Kalarikkal, N., \& Thomas, S. (2021). Recycling of Medical Plastics. Advanced Industrial and Engineering Polymer Research, 4(3), 199-208. https:// doi.org/10.1016/j.aiepr.2021.06.003

Kale, S. (2020). 'We Need to Be Heard': The BAME Climate Activists Who Won't Be Ignored. The Guardian. https:// www.theguardian.com/environment/2020/mar/09/weneed-to-be-heard-the-bame-climate-activists-who-wontbe-ignored
Kibler, E., Wincent, J., Kautoren, T., Cacciotti, G., \& Obschonka, M. (2019). Can Prosocial Motivation Harm Entrepreneurs' Subjective Well-Being? Journal of Business Venturing, 34(4), 608-624. https://doi.org/10. 1016/j.jbusvent.2018.10.003

Kouame, S., Oliver, D., \& Poisson-de-Haro, S. (2015). Can Emotional Differences Be a Strength? Affective Diversity and Managerial Decision Performance. Management Decision, 53(8), 1662-1676. https://doi.org/10. 1108/MD-08-2014-0540

Kratzer, J. (2020). Starting up in the Age of Sustainability. Current Opinion in Green and Sustainable Chemistry, 21, 89-92. https://doi.org/10.1016/j.cogsc.2020.02.003

Kratzer, J., zu knyphausen-Aufseß, D., \& Festel, G. (2021). Glancing through Two Decades of Research on the Human Side of Sustainable Innovation: The Past, the Present, and Directions for Future Research. Sustainability, 13(11), 6355. https://doi.org/10.3390/su13116355

Kuratko, D. F., \& Audretsch, D. (2021). The Future of Entrepreneurship: The Few or the Many? Small Business Economics. https://doi.org/10.1007/s11187-021-00534-0

Kurtis, S. K., \& Mont, O. (2020). Sharing Economy Business Models for Sustainability. Journal of Cleaner Production, 266, 121519. https://doi.org/10.1016/j.jclepro. 2020.121519

Lashitew, A. A., Narayan, S., Rosca, E., \& Bals, L. (2021). Creating Social Value for the 'Base of the Pyramid': An Integrative Review and Research Agenda. Journal of Business Ethics. https://doi.org/10.1007/ s10551-020-04710-2

Ledford, H. (2019). Millions of Black People Affected by Racial Bias in Health-Care Algorithms. Nature, 574, 608-609. https://doi.org/10.1038/d41586-019-03228-6

Longo, C., Shankar, A., \& Nuttall, P. (2019). "It's Not Easy Living a Sustainable Lifestyle": How Greater Knowledge Leads to Dilemmas, Tensions and Paralysis. Journal of Business Ethics, 154, 759-779. https://doi.org/10.1007/ s10551-016-3422-1

Luchs, M. G., Brower, J., \& Chitturi, R. (2012). Product Choice and the Importance of Aesthetic Design Given the Emotion-laden Trade-off between Sustainability and Functional Performance. Journal of Product Innovation Management, 29(6), 903-916. https://doi.org/10.1111/j. 1540-5885.2012.00970.x

Margalida, A., \& Donázar, J. A. (2020). Fake News and Vultures. Nature Sustainability, 3, 492-493. https://doi.org/ 10.1038/s41893-020-0534-5

Maslow, A. (1954). Motivation and Personality. New York, USA: Harper \& Brothers.

Melber, H. (2020). Germany and Namibia: Negotiating Genocide. Journal of Genocide Research, 22(4), 502-514. https://doi.org/10.1080/14623528.2020.1750823

Minton, E. A., Tan, S. J., Tambyah, S. K., \& Liu, R. L. (2020). Drivers of Sustainability and Consumer WellBeing: An Ethically-Based Examination of Religious and Cultural Values. Journal of Business Ethics. https:// doi.org/10.1007/s10551-020-04674-3

Mobbs, D., Hagan, C. C., Dalgleish, T., Silston, B., \& Prevost, C. (2015). The Ecology of Human Fear: Survival Optimization and the Nervous System. Frontiers in 
Neuroscience, 9(55). https://doi.org/10.3389/fnins.2015. 00055

Morris, M. H., Santos, S. C., \& Kuratko, D. F. (2021). The Great Divides in Social Entrepreneurship and Where They Lead us. Small Business Economics, 57, 10891106. https://doi.org/10.1007/s11187-020-00318-y

Moyo, D. (2009). Dead Aid: Why Aid Makes Things Worse and How There is Another Way for Africa. Farrar.

Mueller, T. S. (2021). Blame, Then Shame? Psychological Predictors in Cancel Culture Behavior. Social Science Journal. https://doi.org/10.1080/03623319.2021.1949552

Nicholson, N. (1998). How Hardwired Is Human Behavior? Harvard Business Review. https://hbr.org/1998/07/howhardwired-is-human-behavior

OECD. (2016). States of Fragility 2016: Understanding Violence. $O E C D$. https://doi.org/10.1787/9789264267213-en

O'Shea, G., Farny, S., \& Hakala, H. (2021). The Buzz before Business: A Design Science Study of a Sustainable Entrepreneurial Ecosystem. Small Business Economics, 56, 1097-1120. https://doi.org/10.1007/s11187-019-00256-4

Pansera, M., \& Fressoli, M. (2020). Innovation without Growth: Frameworks for Understanding Technological Change in a Post-Growth Era. Organization, 28(3), 380404. https://doi.org/10.1177/1350508420973631

Patel, R. S., Bachu, R., Adikey, A., Malik, M., \& Shah, M. (2018). Factors Related to Physician Burnout and Its Consequences: A Review. Behavioral Sciences, 8(11), 98. https://doi.org/10.3390/bs8110098

Perea, E., \& Brady, M. (2017). Research Rigor and the Gap between Academic Journals and Business Practitioners. Journal of Management Development, 36(8), 1052-1062. https://doi.org/10.1108/JMD-12-2016-0332

Pereira, I., \& Patel, P. C. (2021). Impact of the COVID-19 Pandemic on the Hours Lost by Self-Employed Racial Minorities: Evidence from Brazil. Small Business Economics. https://doi.org/10.1007/s11187-021-00529-x

Rashid, L. (2019). Entrepreneurship Education and Sustainable Development Goals: A literature Review and a Closer Look at Fragile States and Technology-Enabled Approaches. Sustainability, 11(19), 5343. https://doi.org/ 10.3390/su11195343

Rashid, L., \& Cepeda-Garcia, S. (2021). Self-Categorising and Othering in Migrant Integration: The Case of Entrepreneurs in Berlin. Sustainability, 13(4), 2145. https://doi. org/10.3390/su13042145

Ritch, E. L., \& Schröder, M. J. (2012). Accessing and Affording Sustainability: The Experience of Fashion Consumption within Young Families. International Journal of Consumer Studies, 36(2), 203-210. https://doi.org/10.1111/j. 1470-6431.2011.01088.x

Ritchie, H., \& Roser, M. (2018). Plastic Pollution. Our World in Data. https://ourworldindata.org/plastic-pollution

Sarasvathy, S. (2004). Making It Happen: Beyond Theories of the Firm to Theories of Firm Design. Entrepreneurship Theory and Practice, 28(6), 519-531. https://doi.org/10. 1111/j.1540-6520.2004.00062.x

Sawitri, D. R., Hadiyanto, H., \& Hadi, S. P. (2015). Pro-Environmental Behavior from a Social Cognitive Theory Perspective. Procedia Environmental Sciences, 23, 27-33. https://doi.org/10.1016/j.proenv.2015.01.005
Schaefer, K., Corner, P. D., \& Kearins, K. (2015). Social, Environmental and Sustainable Entrepreneurship Research: What Is Needed for Sustainability-as-Flourishing? Organization and Environment, 28(4), 394-413. https://doi.org/ 10.1177/1086026615621111

Schou, P. K., Bucher, E., \& Waldkirch, M. (2021). Entrepreneurial Learning in Online Communities. Small Business Economics. https://doi.org/10.1007/s11187-021-00502-8

Segers, J., Vloeberghs, D., Henderickx, E., \& Inceoglu, I. (2017). Structuring and Understanding the Coaching Industry: The Coaching Cube. Academy of Management Learning \& Education, 10(2). https://doi.org/10.5465/ amle.10.2.zqr204

Shapiro, J. L. (2016). We Hate What We Fear: Interpersonal Hate from a Clinical Perspective. In The Psychology of Love and Hate in Intimate Relationships (pp. 153177). Cham, Switzerland: Springer. https://doi.org/10. 1007/978-3-319-39277-6_9

Shepherd, D. A., \& Patzelt, H. (2011). The New Field of Sustainable Entrepreneurship: Studying Entrepreneurial Action Linking "What Is to Be Sustained" With "What Is to Be Developed." Entrepreneurship Theory \& Practice, 35(1), 137-163. https://doi.org/10.1111/j.1540-6520. 2010.00426.x

Slavich, G. M. (2020). Social Safety Theory: A Biologically Based Evolutionary Perspective on Life Stress, Health, and Behavior. Annual Review of Clinical Psychology, 16, 265-295.

Spence, M., Gherib, B. B., \& J., \& Ondoua Biwolé, V. (2011). Sustainable Entrepreneurship: Is Entrepreneurial will Enough? A North-South Comparison. Journal of Business Ethics, 99, 335-367. https://doi.org/10.1007/ s10551-010-0656-1

Spohr, D. (2017). Fake News and Ideological Polarization: Filter Bubbles and Selective Exposure on Social Media. Business Information Review, 34(3), 150-160. https://doi. org/10.1177/0266382117722446

Steg, L., \& Vlek, C. (2009). Encouraging Pro-Environmental Behaviour: An Integrative Review and Research Agenda. Journal of Environmental Psychology, 29(3), 309-317. https://doi.org/10.1016/j.jenvp.2008.10.004

Stine, A. (2019). Can You Afford to be Green when You're Not Rich? I Kept a Diary to Find out. The Guardian. https:// www.theguardian.com/lifeandstyle/2019/jul/29/eco-frien dly-going-green-poor-cost-diary

Stirzaker, R., Galloway, L., Muhonen, J., \& Christopoulos, D. (2021). The Drivers of Social Entrepreneurship: Agency, Context, Compassion and Opportunism. International Journal of Entrepreneurial Behavior \& Research, 27(6), 1381-1402. https://doi.org/10.1108/IJEBR-07-2020-0461

Strenger, C., \& Ruttenberg, A. (2008). The Existential Necessity of Midlife Change. Harvard Business Review, 86(2), 82-90.

Sumner, R. C., \& Kinsella, E. L. (2021). Grace Under Pressure: Resilience, Burnout, and Wellbeing in Frontline Workers in the United Kingdom and Republic of Ireland During the SARS-CoV-2 Pandemic. Frontiers in Psychology, 11, 3757. https://doi.org/10.3389/fpsyg.2020.576229

Ulus, E. (2019). A Psychoanalytic Probe into Academic Othering of the United States: Defenses of Splitting and Projection, Consequences, and Alternatives through Emotion 
Work. Organization, 27(3), 515-524. https://doi.org/10. 1177/1350508419876480

van der Kolk, B. A., Perry, J. C., \& Herman, J. L. (1991). Childhood Origins of Self-Destructive Behavior. American Journal of Psychiatry, 148(12), 1665-1671. https:// doi.org/10.1176/ajp.148.12.1665

van Stekelenburg, J. (2017). Radicalization and Violent Emotions. PS: Political Science and Politics, 50(4), 936-939. Radicalization and Violent Emotions

Vandenbroucke, E., Knockaert, M., \& Ucbasaran, D. (2016). Outside Board Human Capital and Early Stage High-Tech Firm Performance. Entrepreneurship Theory \& Practice, 40(4), 759-779. https://doi.org/10.1111/etap.12141

van Goethem, A., van Hoof, A., de Castro, B. O., van Aken, M., \& Hart, D. (2014). The Role of Reflection in the Effects of Community Service on Adolescent Development: A Meta-Analysis. Child Development, 85(6), 21142130. https://doi.org/10.1111/cdev.12274
Wezeman, P. D., Kuimova, A., \& Wezeman, S. T. (2021). Trends in International Arms Transfers 2020 [SIPRI Fact Sheet]. Stockholm International Peace Research Institute.

Wullenkord, M. C., \& Reese, G. (2021). Avoidance, Rationalization, and Denial: Defensive Self-Protection in the Face of Climate Change Negatively Predicts Pro-Environmental Behavior. Journal of Environmental Psychology, 77, 101683. https://doi.org/10.1016/j.jenvp.2021.101683

Publisher's note Springer Nature remains neutral with regard to jurisdictional claims in published maps and institutional affiliations. 